Halaman : $179-184$

\title{
PROFIL SELF REGULATION MAHASISWA PROGRAM STUDI PENDIDIKAN BIOLOGI DI PROVINSI RIAU
}

\author{
Tengku Idris ${ }^{1^{*}}$ \\ ${ }^{1}$ Program Studi Pendidikan Biologi Universitas Islam Riau \\ Jl. Kaharuddin Nasution No.113 KePerhentian Marpoyan Pekanbaru Kode Pos 28284 \\ Email: idrisbio@edu.uir.ac.id
}

\begin{abstract}
ABSTRAK
Self regulationmerupakan kemampuan untuk mengontrol prilaku sendiri, kegiatan ini merupakan salah satu prilaku cerdas dalam menangani suatu permasalahan selain itu juga self regulatioan adalah kontrol terhadap diri sendiri, terutama untuk menjaga diri tetap berada dalam jalur yang sesuai dengan standar yang dikehendaki.Tujuan dari penelitian ini adalah untuk mengetahui profil self regulation mahasiswa Program Studi Pendidikan Biologi di provinsi Riau. Populasi Penelitian ini adalah semua mahasiswa Prodi Pendidikan Biologi yang ada di Provinsi Riau yang terdiri dari 4 Universitas yaitu UNRI, UIR, UNILAK dan UPP sedangkan sampel penelitian ini mahasiswa Prodi Pendidikan Biologi semester 3 dan 5 yang ada di Kota Pekanbaru dengan total sampel sebanyak497 Mahasiswa. Instrument yang digunakan dalam penelitian ini adalah angket yang dikembangkan dari Idris, Sriyati dan Rahmat dengan 5 indikator. Hasil penelitian menunjukkan bahwa self regulationmahasiswa $X$ dalam kategori cukup dengan persentasi sebesar $72.50 \%$, mahasiswa $Y$ sebesar $76.20 \%$ dengan kategori cukup dan mahasiswa $Z$ dengan

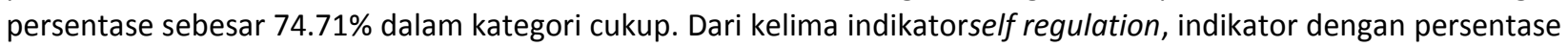
tertinggi terdapat pada indikator 5 yakni mengevaluasi tindakan dengan persentase sebesar $81.24 \%$ dengan kategori baik sedangkan indikator terendah terdapat pada indikator 4 dengan persentase sebesar $66.35 \%$ dalam kateogri rendah. Dari hasil penelitian ini dapat disimpulkan bahwa mahasiswa prodi pendidikan biologi dalam kategori cukup dengan persentase sebesar $74.47 \%$.
\end{abstract}

Kata Kunci: Self regulation, Mahasiswa, Pendidikan Biologi

\section{PENDAHULUAN}

Bangsa Indonesia merupakan bangsa yang besar, yang memiliki potensi untuk menjadi Negara digdaya dengan potensi usia produktif yang sangat besar. Untuk mencetak generasi yang produktif maka pendidikan menjadi ujung tombaknya. Perguruan tinggi yang akan mencetak generasi emas harus mampu mencetak sumber daya yang berkualitas agar siap mendukung cita-cita bangsa. Suksesnya perguruan tinggi dalam mencetak generasi tidak hanya dilihat dari seberapa baik seorang-seorang dalam menguasai pengetahuannya tetapi dapat dilihat juga dari aspek social (mengendalikan diri dan bersosialisasi) serta aspek spiritual (mematuhi ajaran yang dianutnya).

Pengendalian diri (self regulation) merupakan salah satu kebiasaan berfikir (habits of mind) yang sangat penting untuk dilatih dan dimiliki oleh setiap mahasiswa. Dari berbagai media cetak maupun elektronik yang kita baca dan lihat kegiatan demo yang dilakukan mahasiswa selalu berujung bentrok, ini menunjukkan bahwa pembentukan karakter (self regulation) mahasiswa sering terlupakan sehingga banyak mahasiswa cerdas secara akademik tetapi tidak mampu mengatur dirinya (self regulation) dengan baik.

kemampuan untuk mengontrol perilaku sendiri.Regulasi diri merupakan penggunaan suatu proses yang mengaktivasi pemikiran, perilaku dan perasaan yang terus menerus dalam upaya untuk mencapai tujuan yang telah ditetapkan Schunk \& Zimmerman (1998). Selain itu juga menurut Kanfer, 1990: Karoly, 1993 Zimmerman, 2001 (dalam Porath 
\& Bateman, 2006) self regulation adalah sebagai suatu proses yang memungkinkan seseorang untuk memandu aktivitasnya dengan waktu yang lebih lama agar tercapai tujuan yang diinginkannya dan memungkinkan juga untuk mengubah keadaannya menjadi kebalikannya, termasuk dalam pengaturan atau pengaruh pikiran dan perilaku. Individu melakukan pengaturan diri ini dengan mengamati, mempertimbangkan, memberi ganjaran atau hukuman terhadap perilakunya sendiri.Sistem pengaturan diri ini berupa standar-standar bagi tingkah laku seseorang dan kemampuan mengamati diri, menilai diri sendiri, dan memberikan respon terhadap diri sendiri.Selain itu regulasi diri (self regulation) juga merupakan kemampuan mental serta pengendalian emosi Seluruh perkembangan kognitif, fisik, serta pengendalian emosi dan kemampuan sosialisasi yang baik, membawa seseorang untuk dapat mengatur dirinya dengan baik (Papalia \& Olds, 2001).

Self regulation merupakan salah satu komponen yang penting untuk di miliki semua orang.Orang yang mampu mengendalikan diri dengan baik maka dianggap orang yang paling sukses ini tercermin dalam Hadist nabi yang diriwayatkan oleh Ibnu An-Najjar Dari Abu Dzarr yang menyatakan Bahwa "Jihad yang paling utama adalah seseorang berjihad melawan dirinya sendiri dan nafsu". Dari beberapa penelitian yang dilakukan Morosanova \& Fomina, 2017 dan Magi et al., 2016 menunjukkan bahwa self regulation memiliki pengaruh yang sangat penting terhadap kesuksesan dalam ujian dan setiap orang memiliki self regulation yang berbeda-beda.

Regulasi diri merujuk pada dilakukannya kontrol terhadap diri sendiri, terutama untuk menjaga diri tetap berada dalam jalur yang sesuai dengan standar yang dikehendaki (Vohs \& Baumiester, 2004). Regulasi diri merupakan proses penyesuaian yang ber-sifat mengoreksi diri sendiri, yang dibutuhkan untuk menjaga seseorang tetap berada pada jalur menuju tujuan dan penyesuaian tersebut berasal dari dalam diri sendiri (Carver \& Scheier, 2000). Regulasi diri adalah proses seseorang mengaktifkan dan memelihara pikiran, perasaan, dan tindakannya untuk mencapai tujuan personal
(Zimmerman, 2000); baik tujuan yang bersifat akademik, emosional, sosial (Patrick, 1997; Santrock, 2008; Woolfolk, 2010;), dan spiritual (McCullough \& Willoughby, 2009).

Regulasi diri mencakup area kehidupan yang luas, termasuk lingkungan akademik.Pembelajar yang mampu melakukan regulasi diri cenderung berhasil secara akademik. Mereka mampu belajar secara efektif dengan mengkombinasikan keterampilan belajar akademis (academic learning skill) dan kontrol diri yang membuat proses belajar menjadi lebih mudah sehingga mereka lebih termotivasi. Sebagai pembelajar, mereka memiliki dua hal yang diperlukan dalam berprestasi, yaitu keterampilan dan kemauan (Woolfolk, 2010).

Kebanyakan orang menjadi mahasiswa pada masa remaja akhir (usia 17-18 tahun). Pada usia ini, isu kemandirian, kehidupan yang independen dari orangtua, dan karier mulai memuncak (Newman \& Newman, 2009 dalam Husna et al, 2014). Ketika seseorang menjadi mahasiswa, tugas dan tanggung jawabnya tidak hanya seputar diri sendiri dan keluarga, tetapi juga masyarakat.Hal-hal tersebut mempengaruhi bagaimana mahasiswa menentukan tujuan, minat, atau orientasi hidupnya (Husna et al, 2014).

Regulasi diri dipengaruhi oleh ada tidaknya kesempatan (Boekaerts \& Niemivierta, 2000). Mahasiswa akan meregulasi dirinya jika kondisi lingkungan optimal baginya, tidak terlalu mengatur aspek-aspek dari tugas atau tuntutan dan lingkungan belajar serta memberikan kebebasan untuk bertindak dalam mencapai tujuan (Pintrich, 2000). Ketersediaan sumber belajar juga turut berpengaruh karena berkaitan dengan kesempatan yang dimiliki mahasiswa untuk mengembangkan diri dan mempelajari halhal baru lewat sumber-sumber belajar yang tersedia, misalnya buku, jurnal, internet, dan tempat untuk bertanya (Boekaerts \& Niemivierta, 2000). Mahasiswa akan mencari dukungan sosial, seperti afeksi, saran, maupun barang, untuk meningkatkan kemampuan meregulasi diri (Jackson Mackenzie, \& Hobfoll, 2000).

Mengingat urgensi self regulation dalam menentukan kehidupan seseorang, maka dirasa 
Halaman : $179-184$

perlu untuk mengetahui profil self regulationpada mahasiswa sebagai bekal dalam menjalani berbagai permasalahan dalam kehidupan.Informasi mengenai self regulation mahasiswa Program Studi Pendidikan Biologi di Provinsi Riau sejauh ini belum diketahui karena belum ada penelitian yang meneliti hal tersebut.Berdasarkan latar belakang tersebut, maka penelitian ini bertujuan untuk mengetahui profil self regulation mahasiswa Program Studi Pendidikan Biologi di Provinsi Riau.

\section{METODE}

Penelitian bertujuan untuk melihat profil self regulation mahasiswa Program Studi Pendidikan Biologi yang ada di Provinsi Riau. Penelitian ini dilaksanakan di tiga universitas besar yang ada di
Provinsi Riau yakni Universitas Riau (UNRI), Universitas Islam Riau (UIR) dan Universitas Lancang Kuning (UNILAK) yang berada di Kota Pekanbaru. Populasi pada penelitian ini adalah seluruh mahasiswa Program Studi Pendidikan Biologi yang ada di Provinsi Riau di 4 Universitas Yakni UNRI, UIR, UNILAK dan UPP. Sedangkan Sampel penelitian sebanyak 497mahasiswa dari 3 universitas tingkat akademik yang berbeda yakni tingkat 3 (semester 5 ) dan tingkat 2 (semester 3 ).

Instrument yang digunakan pada penelitian ini adalah angket yang dikembangkan dari Sriyati oleh Marzano (1993) Indikator self regulation yang digunakan berasal dari indikator menurut Marzano (1993) yang terdiri dari 5 indikator.Indikatorself regulation dapat dilihat pada Tabel 1.

Table 1. Indikator Self Regulation

\begin{tabular}{ccl}
\hline Aspek & No & \\
\hline & 1 & Menyadari pemikirannya sendiri \\
& 2 & Membuat rencana secara efektif \\
Self regulation & 3 & Menyadari dan menggunakan sumber-sumber informasi yang \\
& & diperlukan \\
& 4 & Sensitif terhadap umpan balik \\
& 5 & Mengevaluasi keefektifan tindakan \\
\hline
\end{tabular}

Data mengenai mahasiswa yang telah dikumpulkan melalui angket selanjutnya dianalisis.Untuk tiap item pernyataan pada angket terdiri dari empat pilihan skor. Analisis data dilakukan dengan cara menghitung persentase beradasarkan skor yang telah dipilih oleh mahasiswa untuk seluruh item kemudian dilakukan interpretasi menjadi beberapa kategori. Kategori baik sekali (86$100 \%)$, kategori baik (76-85\%), kategori cukup (60-
75\%), kategori kurang (55-59\%) dan kategori kurang sekali (s 54\%) (Purwanto, 2008).

\section{HASIL PENELITIAN}

Berdasarkan hasil penelitian yang telah dilakukan maka self regulation mahasiswa Program Studi Pendidikan Biologi dapat di lihat Pada Tabel 2.

Tabel 2. Self regulation Mahasiswa Pendidikan Biologi Se-Riau

\begin{tabular}{|c|c|c|c|c|c|c|}
\hline Aspek & & Indikator & Univ $X$ & Univ Y & Univ Z & $\begin{array}{l}\text { Rata- } \\
\text { Rata }\end{array}$ \\
\hline \multirow{5}{*}{ Self Regulation } & 1 & Menyadari pemikirannya sendiri & 70.58 & 73.00 & 73.10 & 72.23 \\
\hline & 2 & Membuat rencana secara efektif & 72.16 & 78.38 & 72.38 & 74.31 \\
\hline & 3 & $\begin{array}{l}\text { Menyadari dan menggunakan } \\
\text { sumber-sumber informasi yang } \\
\text { diperlukan }\end{array}$ & 75.71 & 79.32 & 79.62 & 78.22 \\
\hline & 4 & Sensitif terhadap umpan balik & 64.54 & 66.92 & 67.59 & 66.35 \\
\hline & 5 & Mengevaluasi keefektifan tindakan & 79.50 & 83.39 & 80.84 & 81.24 \\
\hline & & Rerata & 72.50 & 76.20 & 74.71 & 74.47 \\
\hline
\end{tabular}


Halaman : $179-184$

Berdasarkan Tabel 2 dapat dilihat bahwa secara keseluruhan self regulationmahasiswa Prodi Pendidikan Biologi yang ada di Provinsi Riau dalam Kategori cukup dengan persentase sebesar 74.47\%.jika di dari masing-masing kampus tidak ada perbedaan kategori dari ketiga kampus tersebut semua dalam kategori cukup. Ini menunjukkan bahwa mahasiswa yang berada di kampus negeri maupun swasta memiliki kemampuan pengaturan diri yang sama (cukup). Dari kelima indikatorself regulationindikator mengevaluasi tindakan merupakan indikator tertinggi dengan persentase sebesar $81.24 \%$ dalam kategori cukup sedangkan indikator terendah terdapat pada indikator sensitive terhadap umpan balik hanya mendapat $66.35 \%$ dengan kategori kurang.

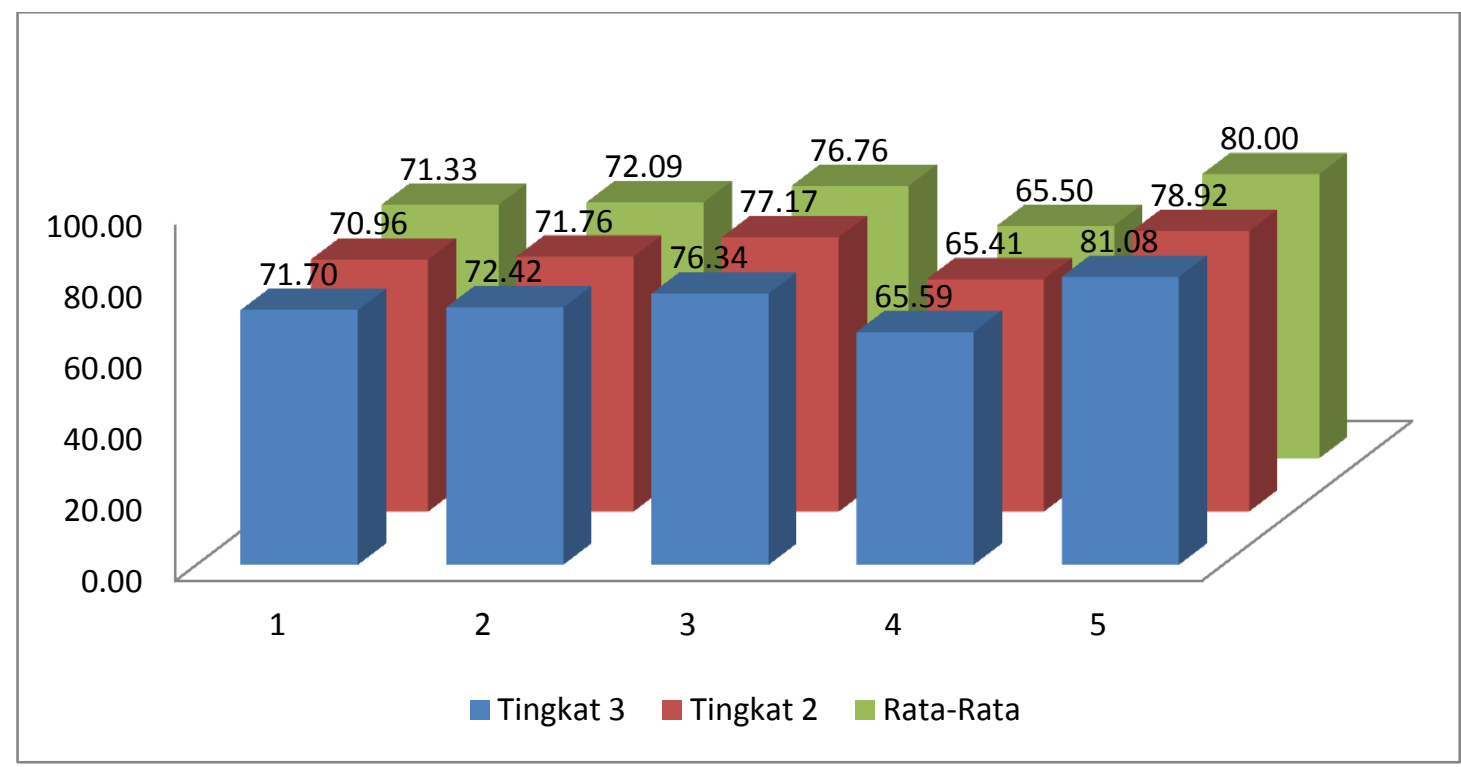

Gambar 1. Self regulation pada Tingkat Akademik. Keterangan: 1. Menyadari pemikirannya sendiri, 2. Membuat rencana secara efektif, 3. Menyadari dan menggunakan sumber-sumber informasi yang diperlukan, 4. Sensitif terhadap umpan balik, 5. Mengevaluasi keefektifan tindakan.

Gambar 1 merupakan deskripsi self regulation pada Tingkat Akademik yang berbeda yakni tingkat 3 dan tingkat 2.Secara umum dapat dilihat bawa tingkat akademik tidak menunjukkan perbedaan yang besar, hampir semua indikator dari self regulation dalam kategori cukup baik pada mahasiswa tingkat 3 maupun pada mahasiswa tingkat 2. Secara rata-rata mahasiswa tingkat 3 lebih tinggi self regulation dengan persentase sebesar 73.43\% sedangkan mahasiswa tingkat 2 memiliki self regulation sebesar $72.84 \%$.tidak berbeda dengan data di atas pada semua tingkat menunjukkan indikator 5 memiliki data tertinggi sedangkan indikatorterendah terdapat pada indikator 4 dengan kategori Kurang.

\section{PEMBAHASAN}

Self regulation menurut Maes \& Gebhardt (2000) yaitu suatu urutan tindakan atau suatu proses yang mengatur tindakan dengan niat untuk mencapai suatu tujuan pribadi. Regulasi diri merupakan kemampuan mengontrol perilaku sendiri adalah salah dari sekian penggerak utama kepribadian manusia (Bandura 1997) Orang yang memiliki self regulation yang baik dia akan sukses secara akademik, social dan spiritual ((Patrick, 1997; Santrock, 2008; Woolfolk, 2010; McCullough \& Willoughby, 2009).

Berdasarkan data penelitian dapat dilihat secara keseluruhan self regulation mahasiswa Program Studi Pendidikan Biologi di Provinsi Riau dalam kategori cukup dengan persentase sebesar $74.47 \%$. Self regulation merupakan kebiasan yang sangat diperlukan oleh mahasiswa untuk mendukung kegiatan belajarnya. Kebiasaan mengatur diri mampu membantu mahasiswa dalam menyelesaikan tugas dan masalah yang dihadapinya. Semakin baik mahasiswa dalam mengatur dirinya maka semakin baik nilai-nilainya dalam perkuliahan. Ini sejalan dengan pernyataan Morosanova dan Fomina (2017) yang menyatakan bahwa self regulation memberikan 
kontribusi yang signifikan terhadap hasil belajar mahasiswa dan self regulation juga bertindak mengontrol emosi, pikiran dan tindakan seseorang yang akan berkontribusi dalam pencapian akademik mahasiswa (Magi et al., 2016).

Dari kelima indikitor yang digunakan berdasarkan habits of mind Marzano 1993, indikator kelima dari self regulation memiliki persentase tertinggi sebesar $81,24 \%$ dengan kategori cuku. Data ini sejalan dengan penelitian yang dilakukan Nurkhairo dan Idris (2016); Idris, Sriyati, Rahmat (2013) dan Sriyati (2011) yang menunjukkan pada semua jenjang pendidikan baik itu mahasiswa maupun siswa indikator mengevaluasi tindakan merupakan persentase tertinggi.

Berdasarkan wawancara dengan mahasiswa mereka mengatakan bahawa mereka tiap semester melakukan evaluasi terhadap proses belajar yang mereka lakukan. Dosen pembimbing akademik membantu mahasiswa untuk mengevaluasi kegiatan belajar dan hasilnya dilihat dari Indeks Prestasi Mahasiswa setiap semester.Menurut Jackson Mackenzie, \& Hobfoll, 2000 Mahasiswa akan mencari dukungan sosial, seperti afeksi, saran, maupun barang, untuk meningkatkan kemampuan meregulasi diri.

Dari Tabel 1 dapat dilihat bahwa indikator sensitiff terhadap umpan balik mendapatkan persentase terendah dengan kategori kurang.Dari angket yang diberikan mahasiswa mengatakan bahwa pembelajaran yang dilakukan sedikit sekali yang memberikan umpan balek terhadap tugas atau kuis sehingga mahasiswa tidak mendapat kesempatan untuk memperbaiki tugasnya. Dari hasil penelitian ini juga menunjukkan bahwa tingkat 3 hanya mendapatkan 4 kali feedback sedangkan mahasiswa tingkat 2 mendapatkan feedback lebih banyak yakni 6 kali.

Dari Gambar 1 ,menunjukkan secara keseluruhan tingkat akademik tidak memiliki pengaruh yang signifikan pada self regulation mahasiswa. Ini menunjukkan bahwa pembelajaran yang terjadi di kampus pada tiap semester kurang melatih kebiasaan siswa daalm mengontol dirinya.Jika kita lihat pada semua aspek menunjukkan mahasiswa tingkat 3 lebih tiap pada semua indikator dibandingkan tingkat 2 tetapi perbedaan itu sangat kecil masih rentang yang sama yakni kategori cukup.Menurut Magi et al, 2016 menyatakan bahwa Perkembangan aspek kognitif dan sikap dari self regulation berbeda secara individu dan hubungan antara aspek kognitif dan sikap dari self regulation berbeda pada titik waktu yang berbeda.

\section{KESIMPULAN}

Berdasarkan penelitian maka dapat disimpulkan bahwa self regulation mahasiswa Program Studi Pendidikan Biologi di Provinsi Riau dalam kategori cukup dengan persentase sebesar 74.74\%, dengan indikator tertinggi terdapat pada indikator 5 yakni mengevaluasi tindakan dan indikator terendah terdapat pada indikator sensitive pada umpan balik. Selain itu juga tingkat akademik tidak memberikan pengaruh yang besar terhadap self regulation mahasiswa dimana mahasiswa tingkat 3 mendapat self regulation dengan persentase 73.43\% sebesar sendangkan mahasiswa tingkat 2 dengan persentase $72.84 \%$ dengan kategori sama sama cukup.

\section{DAFTAR PUSTAKA}

Bandura, Albert. 1997. Self efficacy The Excersice of Control. New York. W.H Freeman and Company.

Boekaerts, M. \& Niemivierta, M. (2000). Selfregulated learning: Finding a balance between learning goals and ego-protective goals. Dalam M. Boekaerts, P. R. Pintrich, \& M. Zeidner (Eds.), Handbook of selfregulation. San Diego: Academic Press.

Haka, N.B., Sriyati., Rahmat, A. (2013) Penerapan Asesmen Kinerja Untuk Meningkatkan Kemampuan Habit of Mind dan Penguasaan Konsep Biologi Siswa Kelas XI. Tesis: Tidak diterbitkan.

Husna, N.A., Hidayati, F. N. \& Ariati, J. 2014. Regulasi Mahasiswa Berprestasi. Jurnal Psikologi Undip Vol. 13. No. 1 April 2014. Hal 50-63.

Idris, T., Sriyati, S., Rahmat, A. 2014.Pengaruh Asesmen Portofolio Terhadap HoM dan Penguasaan Konsep Biologi Siswa.Jurnal Pendidikan Biologi.Vol. 6 No. 1 Hal.671-678.

Idris, T., Sriyati, S., Rahmat, A. 2014.Pengaruh Asesmen Portofolio Terhadap HoM dan Penguasaan Konsep Biologi Siswa pada Materi Sistem Ekskresi dan Sistem Saraf.Tesis: Universitas Pendidikan Indonesia: Tidak Dipublish. 
Halaman : 179 - 184

Jackson, T., Mackenzie, J., \& Hobfoll, S. E. (2000).Communal aspects of selfregulation.Dalam M. Boekaerts, P. R. Pintrich, \& M. Zeidner (Eds.), Handbook of self-regulation. San Diego: Academic Press

Maes, S. \& Gebhardt, W. 2000. Self Regulation and Health Behavior: The Health Behavior Goal Model In M. Boekaerts,O., R. Pintrich \& M.Zeidner (Eds). Handbook of Self Regulation (pp. 343-368). San Diego, CA, US: Academic Press.

Magi, K., Mannama, M. Kikas, E. 2016. Profiles of self-regulation in elementary grades: Relations to math and reading skills. Learning and Individual Differences (51), 3748

Marzano R. J., Pickering and Mc Righe. 1993. Assessing Student Outcomes. Performance Assessment Using the Dimension of Learning Model. Alexandria, Virginia; Association for Supervision and Curriculum Development

McCullough, M. E. \& Willoughby, B. L. B. (2009). Religion, self-regulation, and self-control: Associations, explanations, and implications. Psychological Bulletin,135(1), 69-93.

Morosanova, V.I \& Fomina, T.G. 2017.Self-regulation as a Mediator in the Relationship between Anxiety and Academic Examination Performance. Procedia - Social and Behavioral Sciences 237 ( 2017 ) 1066 1070.

Nurkhairo, H dan Idris, T (2016) Pengaruh Asesmen Portofolio Terhadap Habit of Mind Siswa SMAN Kota Pekanbaru.Laporan Penelitian UIR: Tidak Diterbitkan.

Papalia, Diane \& Feldman, RD. (2008).Human Development. Jakarta: Kencana.

Patrick, H. (1997). Social self-regulation: Exploring the relationship between children's social relationship, academic self-regulation, and school performance. Educational Psychologist, 32(4), 209-220.

Purwanto. 2008. Metodologi Penelitian Kuantitatif, Untuk Psikologi dan Pendidikan. Yogyakarta. Pustaka Pelajar

Sriyati, S. 2011. Penerapan Asesmen Formatif Untuk Membentuk Habits of Mind Mahasiswa
Biologi. Disertasi Sekolah Pascasarjana UPI Bandung:.tidak diterbitkan Stiggins, R. J. (1994). Students centered-Classroom Assessment. New York: Merill Macmillan Colege Publishing Company.

Santrock, J. W. (2008). Educational Psychology. New York: McGraw-Hill.

Woolfolk, A. (2010). Educational psychology. Upper Saddle River, NJ: Pearson Education International.

Zimmerman, B. J. (2000). Attaining selfregulation. Dalam M. Boekaerts, P. R. Pintrich, \& M. Zeidner (Eds.), Handbook of self-regulation. San Diego: Academic Press. 